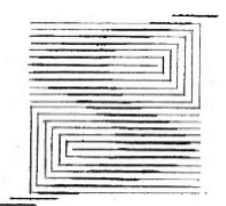




\subsubsection{8}

\section{Things fall apart; The center cannot hold}

Keywords: Home, Modernity, Anthropocene, Anthropocentrism, Imperialism, Inhumanism, Melancholia, Kairos.

By S.E.W. Rasing; S.E.W.Rasing@gmail.com; 4569938

Semester A, 2018/2019

Project: Graduation Explore Lab

Tutor: P.J. Teerds 
THINGS FALL APART; THE CENTER CANNDT HDLD

Essay 

I left New York in 1949,

To go across the country without a bad blame dime.

Montana in the cold cold fall,

Found my father in the gambling hall.

Across to Mississippi, across to Tennessee.

Across the Niagara, home I'll never be.

Home in ol' Medora, home in ol' Truckee.

Apalachicola, home I'll never be.

Road to Opelousas, road to Wounded Knee.

Road to Ogallala, home I'll never be.

Road to Oklahoma, road to Al Cahon.

Road to Tahachapi, road to San Antone.

On the Road, Jack Kerouac 1957 
"I was halfway across America, at the dividing line between the East of my youth and the West of my future." (Kerouac, J. 1957)

Sal Paradise, Jack Kerouac's alter ego in his classic novel On the Road, decides to leave his ancestral home after the death of his father. Recently divorced and only in his early twenties, Paradise fumbled fifty dollars in his pocket for what he states to be 'the beginning of my life on the road'. The act of leaving appeared to him as surprisingly easy. There was nothing desirable, nor any unfulfilled expectations he left behind. It simply was a matter of a heedless mind-set, lured by the image of an unknown world rich in possibilities to be ahead.

Kerouac met Neal Cassidy in New York City, 1946. Sal Paradise stumbled upon Dean Moriarty. A young man raised in the shades of trouble, a figure satisfying the writer's search for the restless inspiration of wandering souls. For the adventurous intellect of outlaws on the run, for characters of the road.

"[...] the only people for me are the mad ones, the ones who are mad to live, mad to talk, mad to be saved, desirous of everything at the same time, the ones who never yawn or say a commonplace thing, but burn, burn, burn like fabulous yellow roman candles exploding like spiders across the stars..." (idem.)

Paradise introduces Moriarty to the local art scene of the late nineteen forties. He meets up with Allen Ginsberg and William S. Burroughs among others, writers and poets who form the basis of what the masses came to know of as the Beat Generation. A literary movement. Dissident product of the post-war economic boom and the fifties' "wholesale reappraisal of conventional structures of society" (Rahn, J. 2011). The Beat movement embodies the spirit of reckless abandon. Inner turmoil and the quest for meaning expressed in poems chanted by lost contemporaries. "Angel headed hipsters burning for the ancient heavenly connection to the starry dynamo in the machinery of night," Ginsberg wrote about 'the best minds of his generation' in his 1956 magnum opus, Howl. A primitivistic tour to the underside of America, where the path of inspiration leads strayed intellect. Those beaten down by the materialistic heaven of Madison Avenue, the national post-war image sold to hungry customers all over the world.

The characters in On the Road, the writers of the Beat movement to whom literary pseudonyms refer for legal reasons, were far from what the later 
popular image suggested. The "Partisan Review's bohemian nihilist and Hollywood's hip hedonist - are almost complete inversions of the character types represented in "On the Road"' (Menand, L. 2007). Instead of hipsters looking for kicks, "the rebels without a cause who point the way for the celebration of the nineteen-sixties" (idem.), the protagonists of the Beat movement represent a generation of sad intellectual minds exhausted by a world producing loneliness, insecurity, and failure. A decade before their free-spirited off the beaten track-attitude became mass-consumed, Kerouac wrote its myth. The myth of a life beyond the formalist modern early twentieth century metropolis. Of spontaneous friendships "who drove cross-country seventy-two hours to find out if I had a vision or you had a vision or he had a vision to find out Eternity" (Ginsberg, A. 1956). Nobody in those days had heard of the word 'hippie', the rival authorities of Vietnam still fought their own fight, the civil rights movement was quite unknown, and the Kennedy's were all alive, and kicking. Even though their adventurous and lively writings became somewhat like the Holy Bible for generations of young Americans to come, celebrating the bold, straightforward, and expressive feelings Kerouac gave words to, the writers of the Beat movement had without any political meaning hit the road west in search of a complete break with past traditions, structural societal believes that did not fulfil their promises of worthy freedom and emancipation (Greenough, S. 2010). Angry young men, as they were popularized in their own days, trying to cope with the uncertainty of days and nights conquering the endless unknown. They took risks in writing by exposing their most deep and honest feelings. Work which was mainly ignored by academic critics and perceived as uncomfortable by the larger public (Menand, L. 2007). Defensive tools like satire and polemic did not conceal nor blur their truth, while "irony was the highbrow virtue of the day, the Beats had none" (Idem.). They found comfort in dissident voices alive hidden in the urban nights. Writers, poets and artists: forlorn people strolling the galleries and bars of Greenwich Village in search of new aesthetical concepts challenging the spiritual emptiness of modern industrialized society.

"You know, everyone I know is kind of furtive, kind of beat... a sort of revolution of the soul, I guess you'd call it." (Holmes, J.C. 1952)

Written over a period of ten years, the idea of hoboes, cowboys and crazy joyrides on endless stretches of asphalt, already had a nostalgic notion when On the Road was published in 1957. The construction of the federal 
highway system was under way, and over those years the amount of cars and trucks registered to drive the intercity roads went from three to thirty million. The romance of long car rides would soon be gone. In addition, the fact that the road, the car, became the place to be for those on the run, is just the result of being in between a city where hopes have been unravelled, and a city in which life still is to be dreamt of. Although it never was their intention, to be nowhere in particular has become a place to settle down. Driving is the way to be together, having no need to answer why, merely wondering what would be next (Menand, L. 2007).

To live unsettled made the Beat writers able to develop their experimental spontaneous prose. It considers the world in a way only the fully receptive observer can. Sketching language, "capturing a segment of time" by an "undisturbed flow from the mind [on] everything that is happening in front of you, [for] there is your poem," Kerouac wrote to Ginsberg on his approach of writing (as cited in Morgan, B. 2006 p. 157158). Desirous for yet undiscovered places, on the hunt for new opportunities, the Beats developed ways to move beyond the procrustean bed of languages describing an unsatisfying narrow world through the eyes of regimes, of power, of former generations, of parents, of teachers. To make room for renewal, for individual interpretation and an expression of the soul in celebration of the divine interconnectedness of the universe and its transitory nature.

The land of the free alongside most of the roads the Beats travelled, was by then still the America of Henry David Thoreau's Walden; or, Life in the Woods. The America of Thomas Jefferson's Declaration of Independence. Home to the humble dream of an agricultural democracy, of farmers rooted independently in their own land. "Those who labour in the earth are the chosen people of God, if ever he had a chosen people, whose breasts he has made his peculiar deposit for substantial and genuine virtue," Jefferson wrote (1787).

But the image of desolate deserts, rolling countryside, deep forests, and a calm Main Street crossing $1^{\text {st }}$ where the local bank serves miners and rural work forces, is by then already in growing contrast with vast metropolitan areas and their development of what once was a shared dream.

John Steinbeck, one of the celebrated literary figures of these areas, contemplated intensively on the status of 'the dream' in the Beat years. Steinbeck's travelogue Travels with Charley: In Search of America, describes his road trip across the country in 1960, when the Beat Generation had spread its presence from New York City's Columbia 
University to the west coast of California. Via Denver to San Francisco, on the verge of dissolving in the Hippie movement, which made their hostile relationship with products of scientific and technological progress, industrial revolution, and far-reaching economic and social changes initiated by capitalist convictions into a 'countercultural' phenomenon. Steinbeck crossed the continent exchanging towns for villages, progress for traditions, utopia for nostalgia, while thriving subcultures began to seriously challenge societal and professional expectations of the new, modern America. A home of the homeless mind; which utopian nakedness is probably best captured in the many photographs of Robert Frank. 


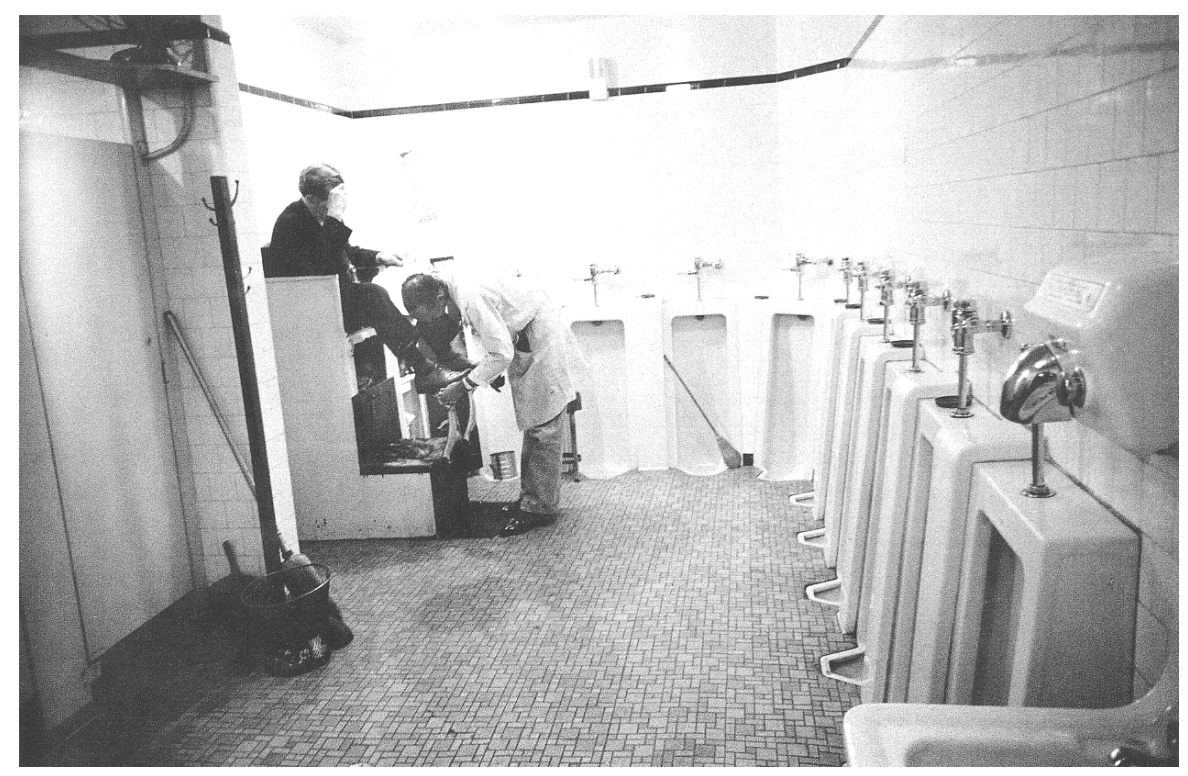

Figure 1. Men's room, railway station by Robert Frank

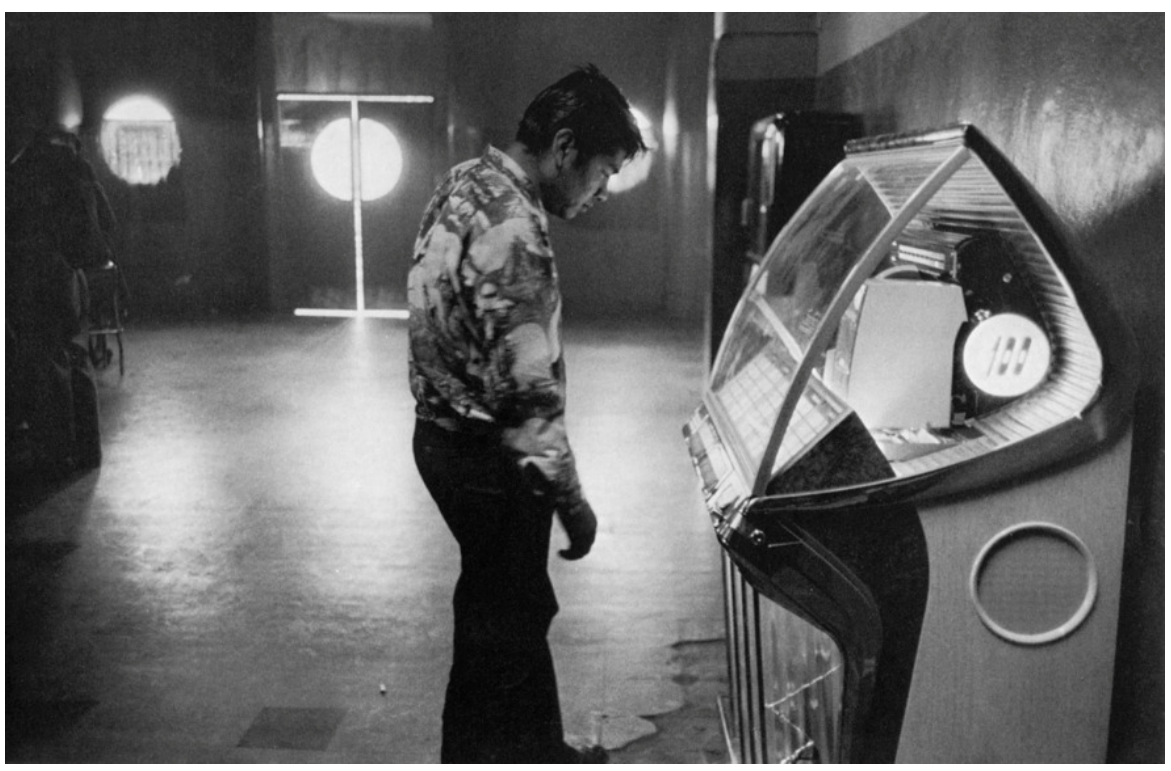

Figure 2. Young man studying jukebox in an empty space by Robert Frank 
The work Frank put together by the name of The Americans (1958) is well known as a sceptical expression of the contemporary values and evocative of ubiquitous loneliness of those days. Kerouac expressed a corresponding societal cynicism in the introduction he wrote for the first American edition.

"Drain your basins in old Ohio and the Indian and the Illini plains, bring your Big Muddy rivers thru Kansas and the mudlands, Yellowstone in the frozen North, punch lake holes in Florida and L.A., raise your cities in the white plain, cast your mountains up, bedawze the west, bedight the west with brave hedgerow cliffs rising to Promethean heights and fame - plant your prisons in the basin of the Utah moon - nudge Canadian groping lands that end in Arctic bays, purl your Mexican ribneck, America - we're going home, going home." (Kerouac, J. 1959, p. 1-3)

Steinbeck, all the way accompanied by his dog Charley, avoided the modernising highlights of America when he could. Although his original intentions were opposite and he blamed himself for doing so, he did. He spoke only by few words of the America of The Americans. The America of the dynamic inner cities of Detroit, Chicago, San Francisco and Seattle, the America of Madison Avenue, the America of the suburbs. His main reason to travel the country about which he wrote intensively was to find out what its inhabitants were like in those days. But just as its youth on the run, he struggled with the new world he witnessed. "I wonder why progress looks so much like destruction" he mentioned (1962).

Steinbeck presented himself as a traditional Jeffersonian American. The playwright and essayist Arthur Miller wrote of him being "a giant man, created for, and drawn by the sun, water and the earth, not suited for sidewalks and mundane societies" (Miller, A.; as cited in Mak, G. 2012). He felt at home amongst the ever quiet people of the countryside, life steeped in unthreatened traditions. Conservative desires for what once was made him feel anxious and alienated from the days' centers of society. But at the same time he owned an apartment in this very New York City, had a big social life and regularly traveled to Paris and London among other European capitals. An inner discord he shared with many, or yet another life on the road. The migrant consciousness of a modern individual (Berger, P.L. Berger, B. Kellner, H. 1973, p. 184).

"I saw in their eyes something I was to see over and over in every part of the nation- a burning desire to go, to move, to get under way, anyplace, away from any Here. They spoke quietly of how they wanted to go someday, to move about, 
free and unanchored, not toward something but away from something. I saw this look and heard this yearning everywhere in every state I visited. Nearly every American hungers to move." (Steinbeck, J. 1962)

Modern citizens traveling the road in order to escape, to get back in time or drive away from what they have, longing for what might be. Their road, that touches upon the horizon in the very end, will never reach the promise made along her miles of asphalt, conrete, dirt, and carved out tracks in which dust and desert meet. For most of them, the American myth dissovled in emptiness.

"Straightening rivers, peopling the solitude, and subduing nature" (Tocqueville, A. de as cited in Miller, D. 2018). The Spanish born, American raised early twentieth century philosopher and writer George Santayana argued Americans living in two separate worlds. One half of their brain perceives the real world, the other half sees a 'moral' world. A world as it should be, that of the dream, but within reach, they think. This practical imagination makes the American live in his future, full of optimism about his 'project of progress' (Mak, G. 2012, p. 183).

Life being feasible has been the strongest belief of American society since its inception, which got to be expressed in the roads taming the West and the grid-drawn cities she raised in white plains. Even the smallest vein of her being was controlled and improved during man's mighty twentieth century. The belief in feasibility offers comfort to those aspiring wealth and success but having to overcome the uncertainty of the actual moment, the confusion of transitory lives in pluralistic structures. Lessons which got wide spread over the Modern West because of their initial success and liberating, comforting narcissistic character. To live well is not about luck or gentle growth. To live well is an activity which can be learned. Which is owned by man. Which should be educated, can be trained and has to be widely examined. Something to start as an amateur and rise in to be a professional some day, as First Lady Eleanor Roosevelt explaines in You Learn by Living. One among many other similar works of an endless amount of American writers (Idem.).

Alexis de Tocqueville wrote already in 1832 of what gave Steinbeck the shivers at times, "A random American will be fervent in his desires. Venterous, adventurous and most of all he will be an innovator. Nothing will stop him from innovating, everything will make him innovate" (as cited in Mak, G. 2012, p. 182). Not nature, not the tree with his roots, not growth is the image an American considers when talking about people or organizations, but the machine. Doing. To create. "While work and 
industry are America's form of civilization, myths are not being dismantled but are rather being created" the English poet W.H. Auden wrote inspired by the promise of America's programmatic approach of modernity in comparison to the struggles of the old continent (as cited in Mak, G. 2012, p. 182).

"With its burgeoning economy and towering military strength, American politics and culture began to seep into every corner of the globe, as did its love of material goods. "It [1943] was the beginning of the 'American century', Ginsberg recalled, "the beginning of hyper-materialism, of the Atomic Era and the Age of Advertising, of Orwellian double-think public language." (Greenough, S. 2010)

Where the writers and poets of the Beat movement wrote the myth of counterculture, James Henry Ford, the typical but legendary pioneer of the American car industry, constructed the inspiration for ordinary Americans. "Two generations of Americans knew more about the Ford coil than the clitoris, about the planetary system of gears than the solar system of stars," Steinbeck wrote in Cannery Row (1945).

In 1945, two years before his death, the journalist John Gunther visited Ford in his private office in Dearborn, a suburb of Detroit. Summum of the world's industry in those days, heaven of steal.

James Henry Ford had been in control of the American automobile market since his factory produced the first Model T. He took risks which only he could afford to take because of his relatively extreme wealth. He introduced an exceptional high minimum wage of five dollars an hour and lowered the costs of his products even in times of economic uncertainty. He drove, in a figurative sense, his competitors crazy, but any worker who did not cooperate had to leave his factory without hesitation. He offered his employers and customers great financial and working conditions but banned unions and spread his anti-Semitic convictions in return.

Ford remained a family company for a remarkably long time, which it could because of Ford's personal fortune back then being three times the entire state budget of Brazil (Mak, G. 2012, p. 180). "His company was by this point [after the second world war] a gigantic concern, an early example of globalization. Ford was already, as Gunther notes, a kind of government in its own right. [...] Ford had no outside stakeholders to satisfy, no banking interests to appease" (Gunther, J.; as cited in Mak, G. 2012, p. 180).

When Gunther visited Ford, the main subject was his museum initiative. The man whose work has destroyed the old America and changed the 
rhythm of the everyday life of the majority of its people, had his scope on Greenfield Village, the town of his youth, for a grandiose replicate of the original celebrated America he knew as a little boy.

"Now, in his old age, out of some kind of psychological displacement or nostalgia, he tinkers with his fingers in a blacksmith shop and looks for oldstyle locomotives that go puff-puff. The man who made the Model T allows no automobiles in Greenfield Village, except in the museum." (Gunther, J.; as cited in Mak, G. 2012, p. 181)

"The museum was intended to take the visitor home, or to the home of a boy called Henry Ford, to the 'good', rural, hardworking America of his youth." (Idem.)

After the interview Gunther left Ford sitting behind his office's practically empty desk, with another table on the side covered in tools and watches. The love of mechanisms, of playing with time and speed, of the manipulation of nature eventually confronted with the harsh character of change, could not have been captured more accurately than John Gunther did in describing his visit to the American dream. James Henry Ford, author of its content, presumably felt the same kind of unease with the eventual new America rolling from the end of his very own assembly line which motivated as well as scared Steinbeck when crossing the continent, and made the Beat Generation travel the roads of literature with a certain sense of fury, in search of a place to call home.

"Insecure as American man can be towards their fellow men," the Brittish cultural anthropologist Geoffrey Gorer wrote in his 1948 book The American People: A Study in National Character, "confident, untroubled, daring and creative like that is his attitude towards matter" (as cited by Mak, G. 2012, p. 182). Steinbeck drew the conclusion that it would be impossible for an American to live in the lonesome, rough and immeasurably vast prairies, mountains and deserts of his country without being inventive and selfconfident as Gorer describes. Without strongly believing in, and holding on to his project of progress (Mak, G. 2012, p. $182)$. 
The meaning of a city was that it made the loneliness bearable.

The Odd Woman and the City, Vivian Gornick 2015 
Matter inventively molded into spaces which man relates to as a place to call home, finds a first serious culmination in the American city of the twentieth century. The confidence man has obtained over the preceding decades in dealing with the physical world is to be found in them sky scraping works of steal and glass drawing the outlines of his presence on the elusive horizon of the earth's surface.

"Steinbeck soon obtained a job working on the construction of Madison Square Garden. For the next few weeks, he pushed 150-pound wheelbarrows of cement all day long. If he wanted to earn overtime - at the rate of $\$ 2$ an hour - he worked 10 to 18 hours a day. [...] But in contrast to the bright lights of Broadway, the partially built Madison Square Garden was as cold and dark as a cave. Construction lights strung along the scaffolds sent long beams down through the planks and gave the men just enough light to know where they were." (Bloom, H. 1988, p. 16)

Steinbeck first came to New York visiting his sister in 1925, he had never been to a city before. The money he gained from the job he obtained at a construction site made him able to stay for a while. He found a room "three flights up in Fort Greene Place in Brooklyn. That is about as alone as you can get" (Steinbeck, J. 1953). The city horified Steinbeck at his arrival. "There was something monstrous about it - the tall buildings looming to the sky and the lights shining through the falling snow. I crept ashore - frightened and cold and with a touch of panic in my stomach" (Idem.). Untill he gave up on urban life and left for California in 1926 to come back again in the fifties, Steinbeck was part of what the architect Rem Koolhaas would half a century later define as the laboratory of 'the Machine Age', a theater of progress.

"A mythical island [Manhattan] where the invention and testing of a metropolitan lifestyle and its attendant architecture could be pursued as a collective experiment in which the entire city became a factory of man-made experience, where the real and the natural ceased to exist." (Koolhaas, R. 1978, p. 9-10) 
At the 'Exhibition of the Industry of All Nations,' held in the fetal New York City of 1853, the inventor Elisha Otis presented a theatrical spectacle which would drastically change the face of America and set the tone for its inner cities. "Otis mounts a platform that ascends - the major part, it seems, of the demonstration. But when it has reached its highest level, an assistant presents Otis with a dagger on a velvet cushion" (Idem., p. 25). Otis cuts the cable which seemed to prevent the platform from falling. Nothing happens. Invisible safety catches, the brilliance of Otis' work, hold the platform in place. "Otis introduces an intervention in urban theatricality: the anti-climax as denouement, the non-event as triumph" (idem., p. 27).

"Manhattan is an accumulation of possible disasters that never happen." (Idem.)

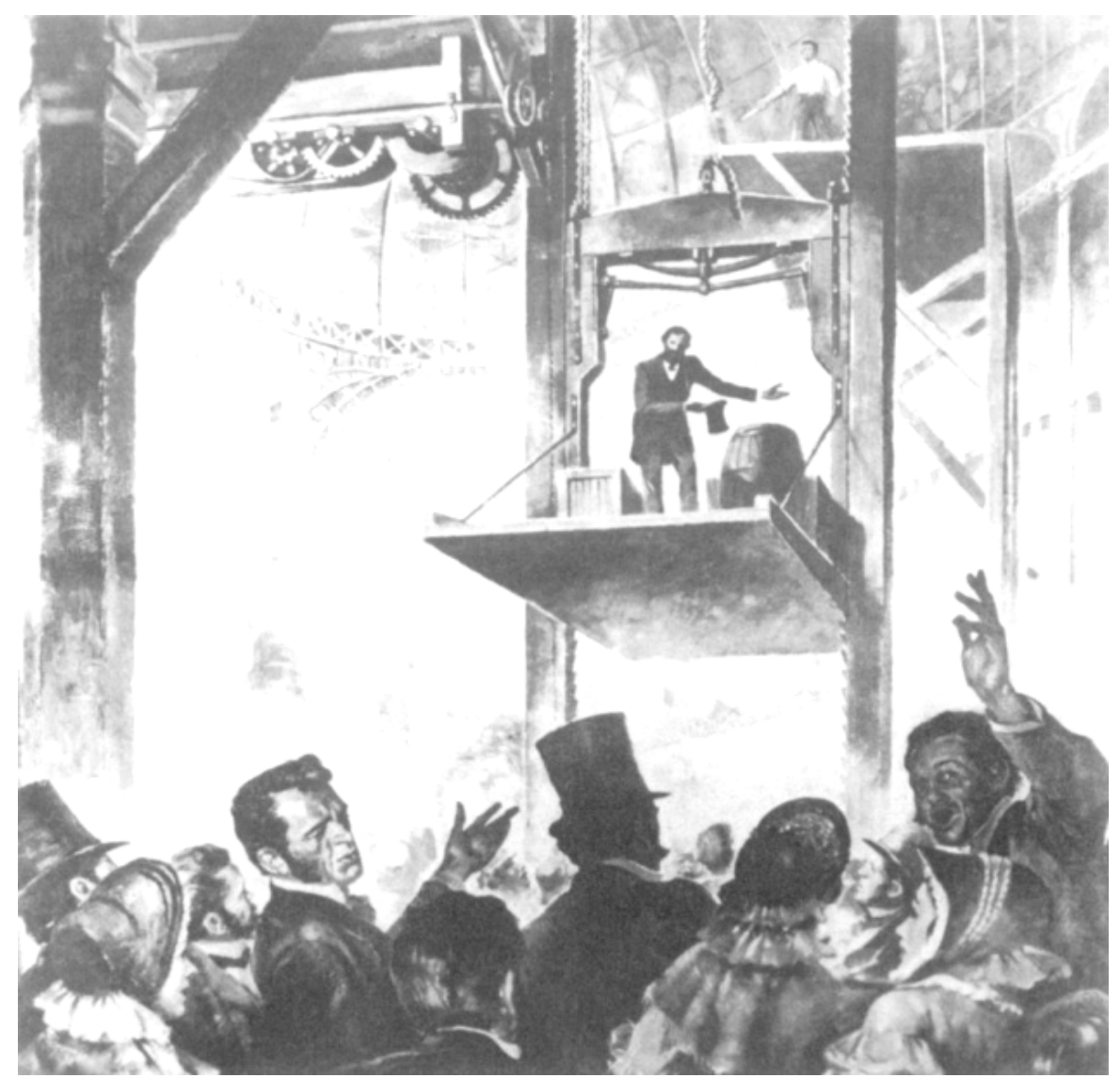

Figure 3. Elisha Graves Otis demonstrates his elevator in New York, 1853 by Bettman/Corbis 
Only a decade after the invention of the elevator, the rich and wealthy northern states of America found themselves in the middle of the American Civil War. The industrial innovative, liberal and relatively rich North had grown so far from the agricultural society of large landowners and plantation slavery of the South, that states separated and collided under president Abraham Lincoln in 1861.

The southern states got defeated by those of the North, which industrial as well as numeral advantage was impossible to be beaten when the right tactics were eventually applied. The North reformed the South and former slaves flee to Northern cities like Chicago and Detroit where there was a tremendous amount of jobs available in what the historian Lewis Mumford defined as the 'Brown Decades' (1931).

Although it was held up by the Civil War, from the 1850's onward life changed rapidly because of many new inventions like Otis' elevator, the steam engine and the invention of the Bessemer process which made the production of steel inexpensive and ready for mass consumption.

"There was a necessity for inventive adaptation which turned men from the inner life to the outer one, and to such manifestations of the inner life as had a plastic or structural equivalent. For a lack of an harmonious system of concepts and feelings, this necessary change did not lead to an intelligent adaptation of the environment. [...] indeed, the new industrial towns were ruins from the beginning. But the necessary invention was present." (Mumford, L. 1931, p. 34)

Walt Whitman, writer of 'Democratic Vistas,' a work which is still considered as the most fundamental piece of literary and social criticism that has ever been written in America, wrote about the years after the war, "A new literature, perhaps a new metaphysics, certainly a new poetry," were necessary as "the only sure and worthy supports and expressions of the American democracy"" (Whitman, W.; as cited by Mumford, L. 1931, p. 30). By now, the task of the arts had changed into a matter of "setting society moving in a direction opposite to that which it had taken offering counterpoises tot the mischievous and ill-fated institutions that had arisen" (Idem., p. 23). The very disorder produced by new interventions and the rapidly rising tide of industrialism combined with the Civil War, became a challenge to the brightest minds of those days.

The physical modernisation of New York City, which Steinbeck so quickly ran away from in 1926, was the most bursting expression of the 
productive tide which the Brown Decades had set moving. Inspired by John A. Roebling's design of the Brooklyn Bridge, the city developed itself by the logic and aesthetics of the machine. With the use of steel in tension, the love for the rough, unadorned reality of the material, and the absence of ornament, the Brooklyn Bridge became a modern architectural vernacular. "The bridge existed in its own right, independent of its influences and potentialities, as a work of art, a delight to the artist and the poet, but equally well appreciated by the man in the street" (Idem., p. 104).

It is here that myths were not being dismantled as on the old continent, but are rather being created. Probably even as drastic as the world has ever seen up until now, life accelerates through a positive people living in the future with at least one half of their brain. On the move once more, nomads in the open vertical direction instead of conquerors westward confronted with rigid and robust mountains or rivers. The land appeared to diminish in importance where even within the city, cities were built. "The greater the distance from the earth, the closer the communication with what remains of nature (i.e., light and air)" (Koolhaas, R. 1978, p. 82). The elevator moves up from floor to floor, virgin sites stacked upon eachother, the profliferation of the earth. "The further it goes up, the more undesirable the circumstances it leaves behind" (Idem.).

"New York, in addition to being a lot of other things, is a Venice in the making, and all the ugly paraphernalia by means of which this making is slowly going forward, all the unlovely processes, physical and chemical, structural and commercial, must be recognized and expressed and by the light of poetic vision be made a part of its beauty and romance." (Hewlett Monroe, J. President of the Architectural league of New York; as cited by Koolhaas, R. 1978, p. 120) 


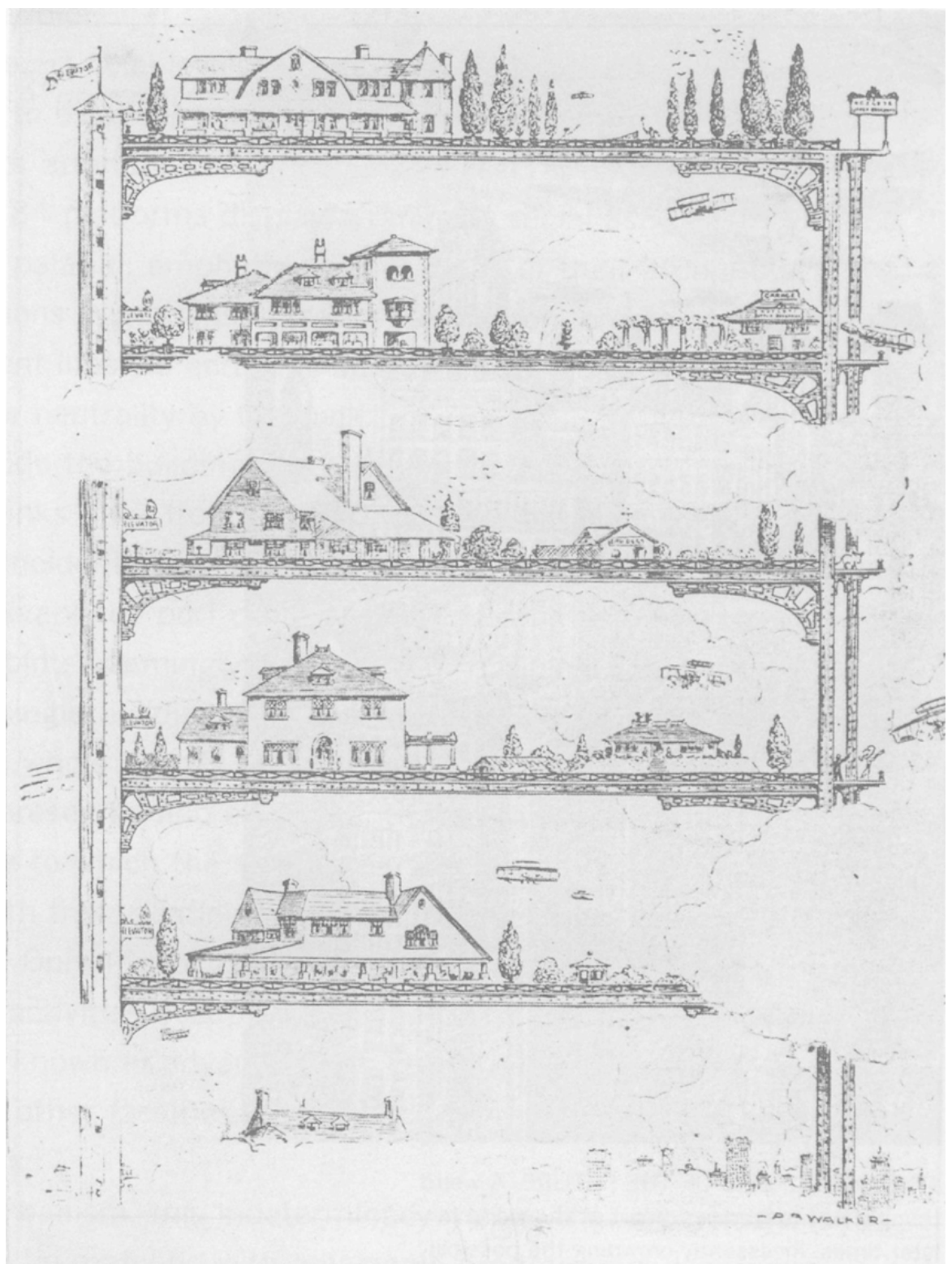

Figure 4. 1909 Theorem: the Skyscraper as utopian device for the production of unlimited numbers of virgin sites on a single metropolitan location. As published in Delirious New York by Rem Koolhaas (p. 83). 


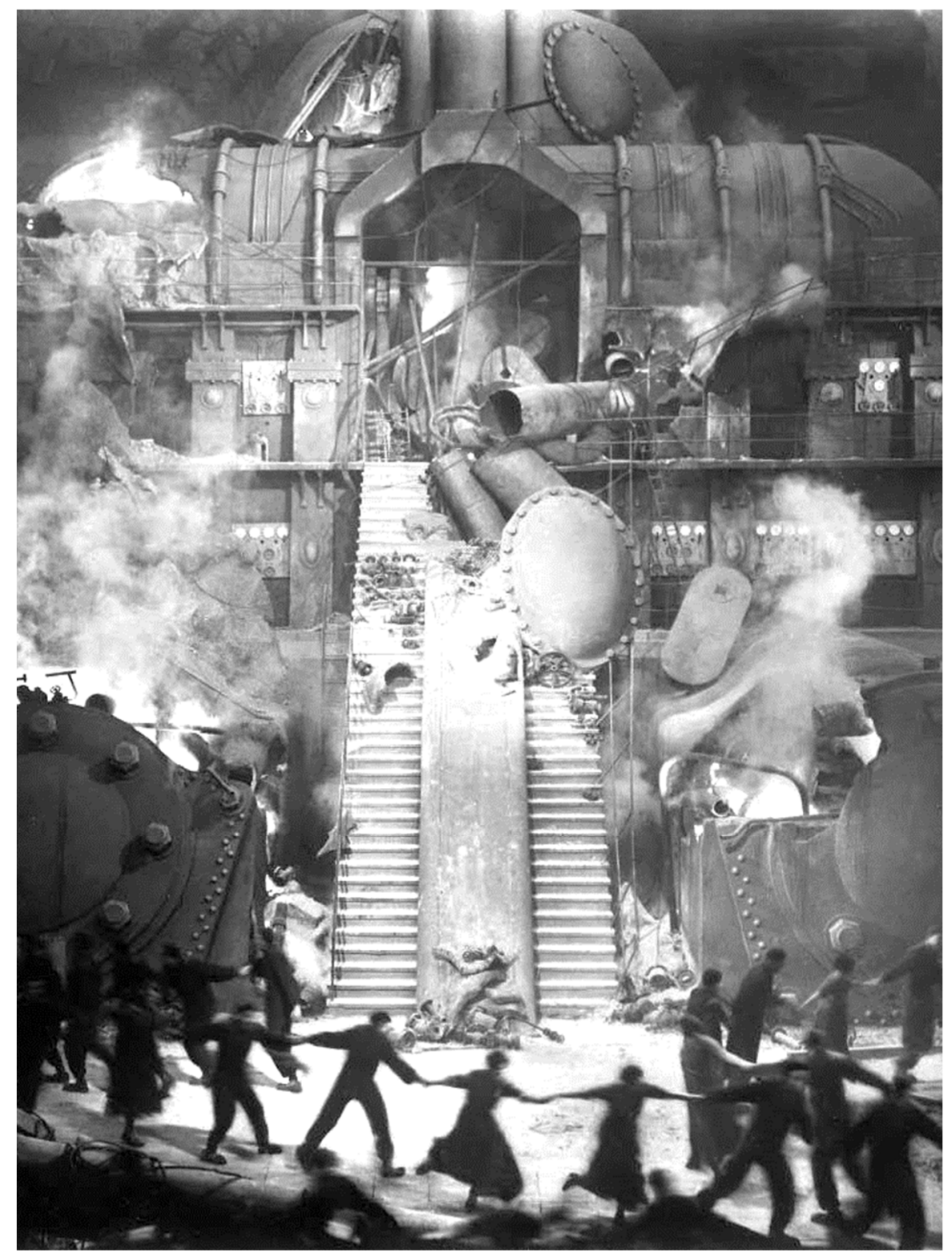

Figure 5. Scene from the film Metropolis, 1927 by Fritz Lang. 
Riders on the storm

Riders on the storm

Into this house we're born

Into this world we're thrown

Like a $\operatorname{dog}$ without a bone

An actor out on loan

Riders on the storm

There's a killer on the road

His brain is squirmin' like a toad

If you give this man a ride

Sweet family will die

Killer on the road

Riders on the Storm, Jim Morrison 1971 
John Steinbeck returned to New York City in 1953. "I didn't leave the city in disgust - I left it with the respect plain, unadulterated fear gives" (Steinbeck, J. 1953).

"New York is an ugly city, a dirty city. Its climate is a scandal, its politics are used to frighten children, its traffic is madness, its competition is murderous. But there is one thing about it-once you have lived in New York and it has become your home, no place else is good enough. [...] It is all of everything. It goes all right. It is tireless and its air is charged with energy." (Idem.)

On his return from the rural states and the struggles of becoming a citizen Steinbeck wrote the article Autobiography: Making of a New Yorker. It covers the many issues which have often been addressed by writers on the modern city. On leaving because of the pressures of a frenetic life and the realization that falling in love with the city ever remains just out of reach. But also on the distant voice which keeps calling. "Homesickness means a dream of belonging; to be, for once, of the place, not merely in," Zygmunt Bauman wrote when theorizing the problems of the rational modern city (Bauman, Z.; as cited by Polak, N. 2018, p. 18). Probably the best known expression of the ambiguous feelings Steinbeck and many of his urban contemporaries had, is the essay Goodbye to All That which Joan Didion wrote in 1967 on loving and leaving New York City.

"New York was no mere city. It was instead an infinitely romantic notion, the mysterious nexus of all love and money and power, the shining and perishable dream itself. [...] I was in love with the city, the way you love the first person who ever touches you and you never love anyone quite that way again." (Didion, J. 1968)

"All I mean is that I was very young in New York, and that at some point the golden rhythm was broken, and I am not that young anymore." (Idem.)

From afar, the American city and its thriving cultural scenes were seen as the ultimate circumstance of life by many. Anthropocentric believes in order, control and predictability, which spread across the whole Western World, find their origin mainly in New York City's appearance of the twentieth century. But what eventually united all forms of modern life is their vulnerability to constant change, of always being 'post-something'. "To 'be modern"," Bauman writes (2000, p. 82), "means to modernize compulsively, obsessively; not so much just 'to be', let alone to keep its identity intact, but forever 'becoming', avoiding completion, staying underdefined." Before the rise of the American city, "to be Modern' "meant to chase 'the final state of perfection' - now [from the 1970's 
onward] it means an infinity of improvement, with no 'final state' in sight and non desired" (idem.). Bauman writes of the "Liquid Modern' as "the growing conviction [of the modern world] that change is the only permanence, and uncertainty the only certainty" (idem.).

"Its [Manhattan's] future can be extrapolated forever: since the exterminating principles never cease to act, it follows that what is refinement one moment will be barbarism the next. Therefore, the performance can never end or even progress in the conventional sense of dramatic plotting; it can only be the cyclic restatement of a single theme: creation and destruction irrevocably interlocked, endlessly re-enacted" (Koolhaas, R. 1978, p. 14).

Liquid modern forms of community, according to Bauman, have "a sense of depthlessness and impermanence" (Blackshaw, T. 2005, p. 104). Just as everything else in places of modernity, community and its institutions are nothing absolute and simply being recycled when the attention and commitment of members decreases. Yet, as Steinbeck, Didion and many others expressed, "this doesn't stop liquid moderns living with a permanent feeling of homesickness, longing for a feeling of home" (idem.).

"Consequently, liquid modern life is pregnant with the wish to settle into some kind of togetherness - to slip under togetherness's safety blanket of certainty and engagement - which community holds as its promise. Part of the reason why that wish is so urgent is because of the larger problem with whole enterprise, which is that liquid moderns know deep down that the settling they are wishing for never occurs." (idem.)

"Homesickness in this sense is hyperreal; liquid moderns do not really long for a home that has been lost; they instead long for something outside themselves that they do not have, or haven't yet been able to find." (Idem.)

The homesickness Bauman writes about is a feeling of nostalgia, a feeling of absences or something lacking in the present. While modernity is defined by constant change and uncertainty, an always renewing present distinguishing itself from the past, man has to destroy himself over and over again in order to keep up. It is the confrontation with the actual moment of the innovative and positive American, spending every 24 hours in their future. 
We tell ourselves stories in order to live.

The White Album, Joan Didion 1979 
"So in America when the sun goes down and I sit on the old brokendown river pier watching the long, long skies over New Jersey and sense all that raw land that rolls in one unbelievable huge bulge over to the West Coast, and all that road ongoing, all the people dreaming of the immensity of it, and in Iowa I know by now the children must be crying in the land where they let the children cry, and the God is Pooh Bear? the evening star must be drooping and shedding her sparkler dims on the prairie, which is just before the coming of complete night that blesses the earth, darkens all rivers, cups the peaks and folds the final shore in, and nobody, nobody knows what's going to happen to anybody besides the forlorn rags of growing old, I think of Dean Moriarty, I even think of Old Dean Moriarty, the father we never found, I think of Dean Moriarty." (Kerouac, J. 1957, p. 320)

The final, lyrical sentence Jack Kerouac wrote in On the Road, famously captures the restless attitude of the, by the time of writing still unknown decades ahead. The more On the Road got to be perceived as a bible for the hippie culture, the more Kerouac's personality became its antithesis. "In his final appearance on television, a falling-down-drunk performance on William F. Buckley's 'Firing Line,' he insisted that his idea of beatness had nothing to do with the hippies (whom he despised)" (Menand, L. 2007). A frustrated writer, a strong Catholic, a man who hated black people and the Jews, who did not take women seriously and detested homophilia, living about three hours north from San Francisco in the solitude of the Big Sur area, was found dead in his lazy afternoon chair at eleven in the morning of the $20^{\text {th }}$ of october 1969. A sharp sting he felt in his stomach made him spit loads of blood. His liver had given up on him after taking a sip of whiskey while writing down some final notes. Kerouac died at 47 years old, Neal Cassady, or Dean Moriarty, had died drunk, high, and half naked next to a Mexican railroad track, about one and a half years earlier.

Kerouac's On the Road holds its place in American literary history as the first nonfiction novel (Menand, L. 2007), being written 'on one long stretch of paper in no more than three weeks'. But Kerouac himself had been planning the plot for seven years and took the trips he wrote about solely for the purpose of literature, instead of being the maniacal wild romantic character which had lighted fire in the readers' eyes. The escapism from the old and the moral fight for a new, free, and still to be unravelled world that seemed to be covered in the stories of the Beats, were the inspiration for a youth who were nostalgically raised with stoic pioneers like John Wayne, in a country which had pushed its frontier already all the way from sea to shining sea. (Vries, J. de 2015)

"There is no American history, there is only the American frontier." (Weiner, M. Mad Men 2007-2015) 
"We stand today at the edge of a new frontier," John F. Kennedy suggested in his 1960 Presidential Nomination Acceptance Speech for his Democratic Party (As cited by Vries, J. de 2015). A new frontier being travels into space, but mainly the voyage of discovery to a new moral standpoint. A new way to relate to the world, to improve it where possible. Guided by a World War II naval hero in significance, an American idol in appearance, until 1963 the American people had a renewed horizon to drive towards, a story in order to live, as Joan Didion critically made history of the American Dream (1979).

In 1967, while living and working in New York, Didion visited one of the many temporary festive hippie settlements in California, the state in which she was born. The story she wrote for The Saturday Evening Post took place in Haight-Ashbury, a district of San Francisco. Didion's anthropological observations of what might be described as 'the end of the road' cover the empty, aimless flower-power-langauge in which the hippies communicated - 'groovy!' (Didion, J. 1967). The way she invades in their habitat and makes their vague confusion hers, gave her an important voice in American, but even so in Western history. Moral clarity, pioneers, heroism, she puts the fictional nature of the American Dream, of the wealthy West and its influences, in stark contrast with the countercultural outcomes of what the Beat Generation had once unsuspectingly initiated: decades of turmoil, violence, apathy, and a shaky morality. Her reference to W.B. Yeats' poem The Second Coming, became a classic in style. Writing, contemplating on a situation favoring the novelistic truth of a writer above the facts of a world which was not to be trusted, later to be defined as 'New Journalism'.

"Things fall apart; the center cannot hold;

Mere anarchy is loosed upon the world...

Surely some revelation is at hand;

Surely the Second Coming is at hand...

And what rough beast, its hour come round at last,

Slouches towards Bethlehem to be born?"

(Yeats, W.B.; As cited by Didion, J. 1967)

We tell ourselves stories in order to live, to be able to process the ambiguity and intricate events unfolding in our everyday lives. In us lives a yearning for clarity, for this being this, and that being that. For borders, for defintion, for a hero and a crook, for a good and a bad, for a horizon, for a road.

Different from other New Journalism-writers, Didion did not march along with countercultural movements. "Nothing was irrevocable; everything was within reach," she wrote at first when moving to New York City in 
the late 1950's (1968), to eventually find out about the same meaningless, spiritual emptiness of the 'free world'. Just as the Beats and Steinbeck struggled, she saw progress but felt the ruins it left behind even more. "It is easy to see the beginning of things, and harder to see the ends," she mentioned in Goodbye To All That (idem.), being at home in New York City was kept out of reach by New York City.

For Didion, contemplating on America, the 1960's were the time when 'the story', the dream, lost its strength for good. When all orderliness we expected in life and society could be thrown away. There is always a story of a story, of a story. So in order to understand and deal with the world in which we live, it is not the outcome, the story itself, which should be of our interest, but the cultural matrix behind its production and popularization (Vries, J. de 2019).

"Culture generates desires - for vehicles and appliances, for certain kinds of gardens and dwellings," the Indian writer Amitav Ghosh writes in his 2017 book The Great Derangement. "A speedy convertible excites us neither because of any love for metal and chrome, nor because of an abstract understanding of its engineering. It excites us because it evokes an image of a road arrowing through a pristine landscape; we think of freedom and the wind in our hair; we envision James Dean and Peter Fonda racing toward the horizon; we think also of Jack Kerouac and Vladimir Nabokov" (Ghosh, A. 2017, p. 10). The stories we tell and live by, the things we desire and the artefacts which make up our world, are "at once expressions and concealments of the cultural matrix that brought them into being" (Idem.).

According to Joan Didion's main message throughout all of her work, every story, in fact every outcome of the cultural matrix, is a construct of man. A construct which can fall apart, of which the center cannot hold. A construct we cannot trust.

Decades before Jack Kerouac moved out of San Francisco to the Big Sur area finding the solitude which eventually became the stage of his death, the poet Robinson Jeffers built his own house out of hand-carved granite in the same area. Jeffers' attempt to withdraw from society has been the story which tempted Kerouac, among several other writers from the Beat Movement, after his life on the road. In disguise of what his work and believes had turned into, he escaped.

As a poet, Jeffers wrote extensive poems filled with critiques on modern society. He introduced his collected thoughts under the name of Inhumanism, detesting the solipsism of humanity, the narcisistic character of man and his indifferent attitude towards nature. What he 
saw was a mass, intoxicated by its own technological, political, and civilized ingenuity, which had destroyed its alliance with the earth.

"The extraordinary patience of things!

This beautiful place defaced with a crop of suburban houses -

How beautiful when we first beheld it,

Unbroken field of poppy and lupin walled with clean cliffs;

No intrusion but two or three horses pasturing,

Or a few milch cows rubbing their flanks on the outcrop of rock-heads-

Now the spoiler has come: does it care?

Not faintly. It has all time. It knows the people are a tide

That swells and in time will ebb, and all

Their works dissolve. Meanwhile the image of the pristine beauty

Lives in the very grain of the granite,

We must uncenter our minds from ourselves;

We must unhumanize our views a little, and become confident

As the rock and ocean that we were made from."

(Jeffers, R.; As collected by Hunt, T. 2001 p. 676) 
Recognition is famously a passage from ignorance to knowledge.

The Great Derangement, Amitav Ghosh 2017 
The rocks in which Kerouac after Jeffers had find a home in a practical as well as spiritual sense, still rise firmly out of the tides of the Pacific Ocean. The foothills of the Santa-Lucia Range now, we speak of 2018, carry one of the most beautiful highways of the United States of America towards spectacular views, along enormous trees and small wooden cabins. The rough landscape has become the subject of articles in travel guides, magazines and real estate brochures. The stories of ancient men finding their solitude in the serenity of the area's natural beauty, attracts many Kerouac-fanatics and citizens of San Francisco on their Sunday off. The world's unstoppable innovation has its most recent symbol at a three hour drive away from one of its historical hideouts. Scenic Rd, Inspiration Ave, they now offer a comfortable route through loneliness, to the stories of men we will never know.

In 2013, a famous Silicon Valley-investor hand-picked the area for his marriage. At the cost of milions of dollars he made the situation "extra fairylike'. Trees were cut, concrete poured and decorative bridges were built out of boulders from afar. He eventually had to pay a fine for the damage his marriage had caused to the natural beauty (Kleinpaste, $\mathrm{T}$. 2015 p. $20-23)$.

The rough landscape, its breathtaking views, the solitary feeling, there were times when man feared the immeasurable surface and depth of the ocean and the darkness of an empty woods as one can find in the Big Sur area. Even times when they were thought of as bewitched and filled with horrible powers. Today, they have become a favoured location for brides and grooms, honeymoons and amateur photographers. A place to find peace on a Sunday afternoon walk, and to live if one has succeeded as a professional in life. Breathtaking has surely lost its negative notion. Quite like New York City, man fought instead of feared nature and created new, modern myths. Pushed the frontier, rose above the rock and ocean, and made his story of the earth.

"The earliest European settlements [1524] in what is now New York State, were built a long way up the Hudson River," Amitav Ghosh writes about the growth of an imperialistic attitude in man during colonial eras (2017 p. 37), [...] "It was not til 1625 that the Dutch built Fort Amsterdam on Manhattan Island." The British seized the settlement in the 1660s and developed both at the same time the city of Mumbai as well as New York in estuarine regions, where the relationship of land with the ocean was extremely porous and variable with tides and seasons. The British distinctively separated both, "The reshaping of the estuarine landscape [of Mumbai] proceeded at such pace that by the $1860 \mathrm{~s}$ a Marathi Chronicler, Govind Narayan, was able to predict with confidence that soon it would never occur to anybody that Mumbai was an island once" (Idem. p. 39). 
European colonists founded cities like Chennai, Charleston, Boston, and Kolkata all directly on the shores and islands of fragile landscapes which were easy to supply and defend. A century later and with even more confidence, places like Singapore and Hong Kong got developed into modern metropolises. Where the old ports of Europe and Asia were situated deeper inland with great wariness of the ocean, "A colonial vision of the world, in which proximity to the water represents power and security, mastery and conquest, has now been incorporated into the very foundations of middle-class patterns of living across the globe" (Idem. p. 37). The ocean view has become even more expensive than the house itself.

Nowadays, 11.8 million souls find their home on the most southern former islands of Mumbai. Far Rockaway and Long Beach, neighborhoods on former barrier islands alongside the coast of New York State, are some of the most favourable places to live or spend the days off for wealthy citizens.

It struck Ghosh to see when visiting the Malaysian shore side town of Malacca in the tsunami-area of 2004, that even in places "as far removed as possible from the metropolitan centers that have shaped middle-class lifestyles, the pattern of settlement had come to reflect the uniformitarian expectations that are rooted in the "regularity of bourgeois life"" (Idem. p. 35).

"Of the houses only the floors were left, and here and there the stump of a wall. It was as though the place had been hit by a bomb specifically to destroy all things human" (Idem. p. 33).

Where the shores were damaged, the interior seemed unaffected. The houses of indigenous islanders had, opposite to those of the more wealthy and educated people from the mainland living with an ocean view, stayed untouched.

In 2012, large parts of Long Island got flooded due to Hurricane Sandy. Houses, planned in an ordered geometry sanctioned by the state, got washed away as if they were dirt on a skin.

"It was generally believed that "losing one's life to a hurricane is... something that happens in far-away places"” (Idem. p.26). 


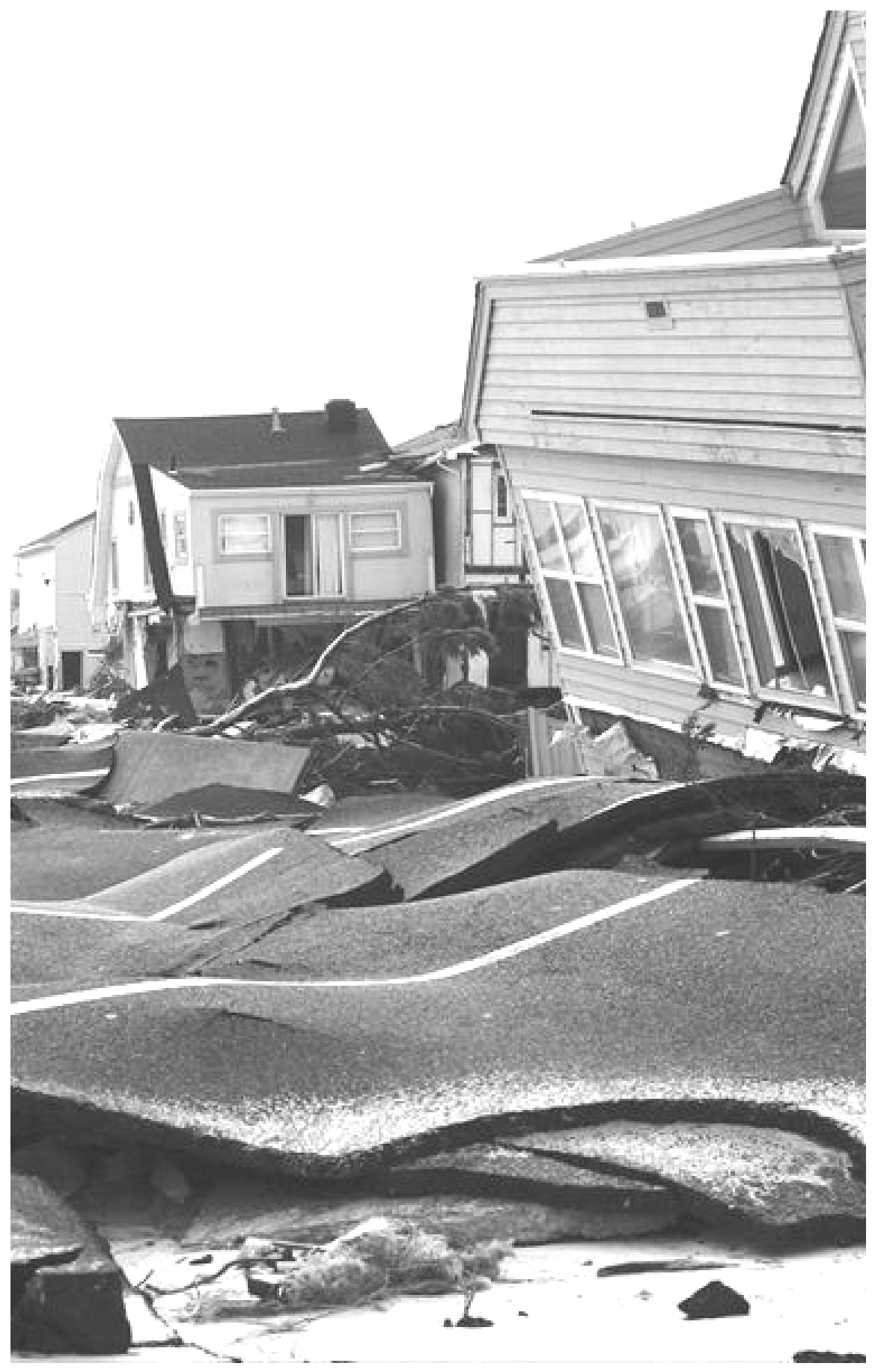

Figure 6. Long Beach residences damaged after Hurricane Sandy, 2012. 
"Reading about Hurricane Sandy, I came upon more and more evidence that climate change may indeed alter patterns of cyclonic activity around the world. When I began to look for information on the Arabian Sea in particular, I learned that there had been an uptick in cyclonic activity in those waters over the last couple of decades" (Idem. p. 40).

Geologists, chemists, environmental researchers and many other branches of science have recently proposed the end of the relatively calm Holocene geological epoch. According to many, we have entered "a more volatile period," (Blasdel, A. 2017) defined as the Anthropocene era. "The term Anthropocene, from the Greek word Anthropos, meaning 'human', acknowledges that humans are the major cause of the earth's current transformation" (Idem.). When examining the layers of the earth, as we have always done in order to trace the history of life on this very planet, we can by now clearly identify our presence as a species. While scientific debates are still ongoing about when this change has occurred exactly, may it be when European explorers went overseas, when industrialization got serious proportions, or when for example the first atomic bomb was succesfull in drastically changing an environment at once, the official proposal of the Anthropocene is shaking the relationship between man and his environment. An awareness of itself as a force of great influence on the planet tries to get into the construct of man.

"We live in a world with moral calculus that didn't exist before. ... What began as a technical debate within the earth sciences has led, in Morton's view, to a confrontation with some of our most basic ways of understanding the world" (Morton, T. 2009).

Philosophers like Bruno Latour and Timothy Morton suggest the rejection of the separation made in the Enlightenment between subject and object, between nature and culture, non-human and human. The main issue which confronts man is that of what Morton describes as 'hyper objects," "the presence of ginormous things," [...] "such as global warming or the internet - that we tend to think of as abstract ideas because we can't get our heads around them, but that are nevertheless as real as hammers" (idem.). Bruno Latour, writer of We Have Never Been Modern, states, "Until about two centuries ago, nature played a role as scenery in Western Society. But ever since, it became part of the play" (As said in Oey, 2017). With the Anthropocene, we are confronted with the fact that we never controlled or stood apart from non-human things on the planet, "In contrast to utopian fantasies that we will be saved by the rise of artificial intelligence or some other new technology, the Anthropocene teaches us that we can't transcend our limitations or our reliance on other beings. We can only live with them" (Morton, T. 2009). 
Digital worlds, digital lives, genetically modified food, robotics, techniques of reproduction, they blur the traditional separation between human and non-human. According to post-humanists like Rosi Braidotti, these developments offer solutions to give meaning to the flexible and pluralistic identities of man. To leave humanist ideas behind for new sorts of social bonding and communal living (Braidotti, R. 2013). In 1957 the biologist Julian Huxley wrote, "I believe in transhumanism: once there are enough people who can truly say that, the human species will be on the threshold of a new kind of existence, as different from ours as ours is from that of Peking man. It will at last be consciously fulfilling its real destiny" (Huxley, J. 1957 p. 13-17).

Many tech-businesses in Sillicon Valley work from trans-human ideas. Turning the body and lives into data, trying to overcome the deficiency of man, aiming at the realisation of the human dream or deepening the American dream according to their cultural roots. Latour suggests, as a post-humanist strategy, giving human voices to non-human artifacts and systems in order to get them involved in debates on the future in what he has defined as 'the Parliament of Things' (Bauwens, L. 2018).

Futuristic movements and a growing group of philosophers agree on the fact that the perception man has of his relationship with the earth, the story he wrote and built, is too limited to cope with the questions the Anthropocene poses. But solutions of adding "post-' or "trans-" to the word human still center the perspective and structures of man, they do not overcome the dichotomic existence of human and non-human while having their origin in the cultural matrix which has driven all the other attempts of man to live in a place where things fall apart and the center cannot hold. Concealments, in order to prevent mere anarchy from being loosed upon the world.

"Machines are concealed wishes of actants which have tamed forces so effectively that they no longer look like forces," he writes (Latour, B. 1993).

Concealments of the realities of his plight in order to be able to keep up developing his modern, anthropocentric reassurance. But where beauty is not anymore in the persons but in the disastrous rhythm, "the heavy and mobile masses, the dance of the dream-led masses down the dark mountain," as Robinson Jeffers wrote in Rearmament (As collected by Hunt, T. 2001 p. 513).

To be able to deal with Anthropocentric crises such as climate change and other 'hyper objects' as Morton defines them, man must recognize these issues as a challenge to our common sense understandings, a cultural crisis, a crisis of imagination. "Recognition is famously a passage from ignorance to knowledge," Amitav Ghosh writes (2017 p. 9). 
"The most important element of the word recognition thus lies in its first syllable, which harks back to something prior, an already existing awareness that makes possible the passage from ignorance to knowledge: a moment of recognition occurs when a prior awareness flashes before us, effecting an instant change in our understanding of that which is beheld. Yet this flash cannot appear spontaneously; it cannot disclose itself except in the presence of something new: it arises rather from a renewed reckoning with a potentiality that lies within oneself" (idem. p. 4).

A more suitable balance between the human and non-human in a time when the wild has become the norm, does not have to mean a rejection of humanism or the project of man. It can also mean changes within the humanist ideas of Enlightenment. A devotion to, and a constant questioning of what it means to be human. In fact what Joan Didion and even the Beat movement tried, to be fragile, to put one's understanding and ideas continuously into challenging situations instead of the cultural blanket of concealment. Coming from the position of man in the first place, which has always been situated in nature as well as technology, then getting rid of everything fixed and evident and looking at reason as a "constructable hypothesis, a space for navigation and intervention" (Negaristani, R. 2014).

"Freedom is not the liberation from slavery. It is the continuous unlearning of slavery," the Iranian philosopher Reza Negaristani writes when introducing a strategy he named after Jeffers' Inhumanism. By acknowledging instead of rejecting that technological and natural incomprehensibilities are not something outside of the human, but being human precisely exists out of the continuous scanning and incorporation of it, it becomes possible to confront oneself with the non-human actors and their effects on being human. By considering the human mind as 'artifactual', an object made by human beings, it can be leveled with non-human actors and be reckognized as a part of this (Bauwens, L. 2018).

Coming from an Inhumanist perspective, "the questions that confront writers and artists today are not just those of the politics of carbon economy; many of them have to do also with our own practices and the ways in which they make us complicit in the concealments of the broader culture. For instance: if contemporary architecture, even in this period of accelerating carbon emissions, favour shiny, glass-and-metal-plated towers, do we not have to ask, what are the patterns of desire that are fed by these gestures?" (Ghosh, A. 2017 p. 10). 
I write...

I write: I write...

I write: 'I write...'

I write that I write...

etc.

I write: I trace words on a page.

Letter by letter, a text forms, affirms itself, is confirmed, is frozen, is fixed:

a fairly strictly $h$

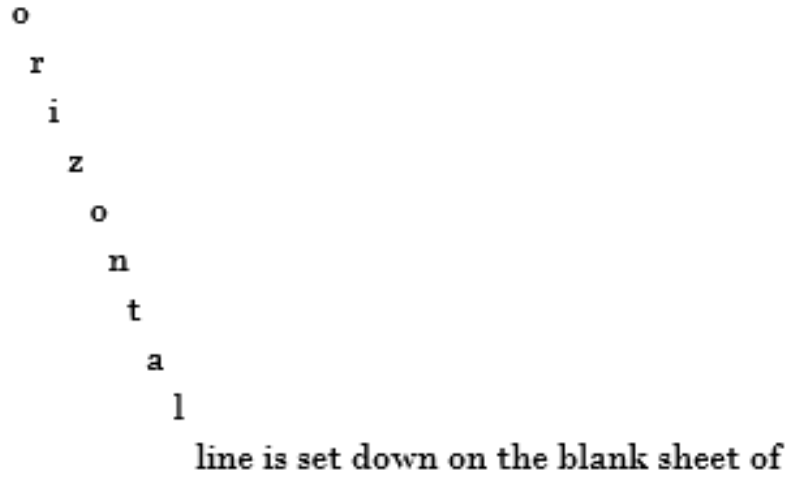

paper, blackens the virgin space, gives it a direction, vectorizes it: from left

to right

f

$\mathbf{r}$

0

$\mathrm{m}$

$\mathrm{t}$

o

p

t

o

b

o

$\mathrm{t}$

t

o

$\mathrm{m}$ 
"Before, there was nothing, or almost nothing, afterwards, there isn't much, a few signs, but which are enough for there to be a top and a bottom, a beginning and an end, a right and a left, a recto and a verso." (Perec, G. 1997, p. 9)

The page is the spatial reality of the essay. Tracing the edges, stumbling upon its centre point after wandering in sentences from off the top towards its bottom. Being struck halfway by the edge ahead, thoughts get further selected and condensed through projection in words. Dividing the whole in chapters and paragraphs. Towns and neighbourhoods, streets and squares. Words are given, the landscape arises. Forms, informs and gets formed. The writer lives in the space of his page. The writer "writes in order to peruse himself", the Belgian poet Henri Michaux said.

Commissioned by his friend Paul Virilio, who was an architectural theorist in the 1970's, George Perec wrote the essay 'Species of Spaces', exploring the concept of space. "Whimsical, thoughtful, confessional, and provocative in turns, it has a disarming simplicity of style, and for many French readers, is the quintessence of Perec's art and mind" (Bellos, D. 1999). In order to examine the notion of space, Perec devotes every new chapter of the essay to his associations regarding an increased scale of the subject. A subject he defines as "not the void exactly, but rather what there is round about or inside it" (Perec, G. 1997, p. 5). He moves from the space of the bed to that of the bedroom, from the space of the apartment to the space of its building. From the street to the neighbourhood and from the town to the countryside. After which he examines the space of a country, that of Europe, of the Old Continent, the New Continent and the space of the World to end with.

"The world is big.

Aeroplanes crisscross it at all times and in all directions." (Idem. p. 77)

"The surprise and disapointment of travelling. The illusion of having overcome distance, of having erased time.

To be far away." (idem.)

"This is how space begins", Perec writes in the very first chapter, preceding the bed, "with words only, signs traced on the blank page. To describe space: to name it, to trace it, like those Portolano-makers who saturated the coastlines with the names of harbours, the names of capes, 
the names of inlets, until in the end the land was only separated from the sea by a continuous ribbon of text" (p. 13) (fig. 4). As if all spaces could be captured within the alphabet. Space as inventory. Space as an encyclopaedia, clear and fixed. Space as place.

"O God! I could be bounded in a nutshell, and count myself a King of infinite space..." (Shakespeare, W. Hamlet, II, 2; as cited in Borges, J.L. 1945) 


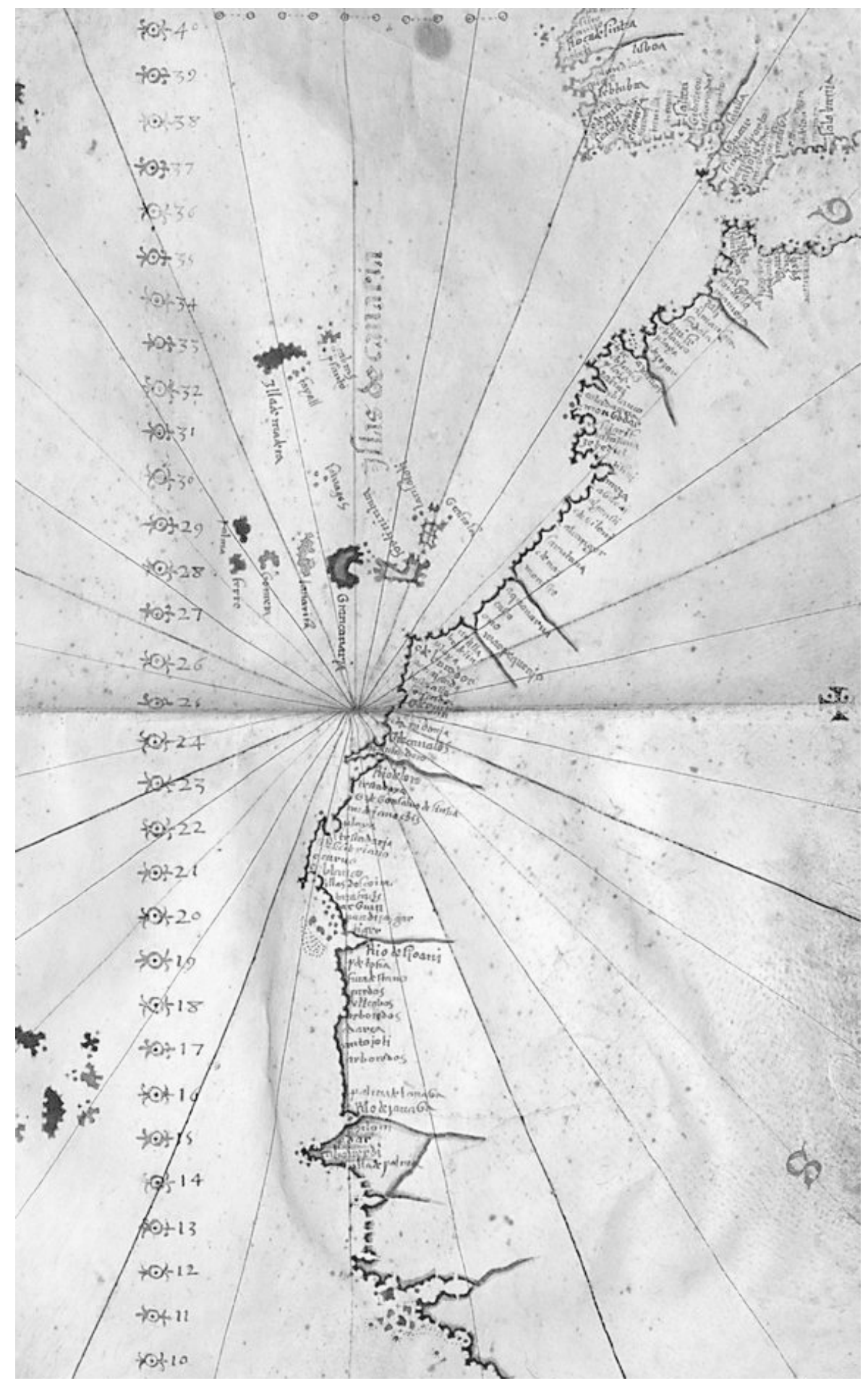

Figure 7. Portolan nautical chart of the Spanish Canary archipelago, $14^{\text {th }}$ century. 
If one wants to examine the being of a culture, her understanding, design and experience of the spaces she inhabits are priviliged expressions to work with. "Die Art der Ausgedehntheit soll... das Ursymbol einer Kultur genannt werden" (Spengler, O. Der Untergang des Abendlandes; as cited in Lemaire, T. 1970, p. 18). Space is the surface on which a culture, an era, an individual projects his order of life. His past and longings (Lemaire, T. 1970, p. 18). Modern man lives in these spaces that seem obvious. The neighbourhood, the parks, the alleys and the countryside, they seem self-evident. The house and the appartment building, they can see and touch them. The street and the station's corridor, they're real and rational. But not just a matter of course. Perec writes, "What's certain in any case, is that at a time too remote for any of us to have retained anything like a precise memory of it, there was none of all this: neither corridors, nor parks, nor towns, nor countryside" (Perec, G. 1997, p. 5).

"There isn't one space, a beautiful space, a beautiful space all around us, there's a whole lot of small bits of space, and one of these bits is a Métro corridor, and another of them is a public park. Another-and here we suddenly enter into much more particularized spaces - originally quite modest in size, has attained fairly colossal dimensions and has become Paris." (Idem., p. 6)

By now, in a far developed civilized state, there are spaces in every size for every function. The ambient space has been, and is endlessly being broken up. Diversified and multiplied. "To live is to pass from one space to another, while doing your very best not to bump yourself," Perec writes (idem.).

Developing the world with the technical ingenuity of today, is as if one writes a novel in the spatial sense. "A setting allows stories to unfold," a "sense of place" is "famously one of the great conjurations of the novel as a form" (Ghosh, A. 2017 p. 58). Surveyors, just as writers, construct a setting by making discontinuities. To make a site particular to itself, it is loosened from the world beyond. It is a modern habit of mind to break problems into pieces until a solution presents itself. The deliberate exclusion of things and forces which do not have obvious immediate links with the matter at hand, renders the interconnectedness of the whole unthinkable.

"It is through the impositions of these boundaries, in time and space, that the world of a novel is created: like the margins of a page, these borders render places into texts, so that they can be read" (Idem. p. 59).

In stories, a setting becomes a self-contained ecosystem, sustaining life and narrative by excluding inconceivably large forces and by focussing the changes on a limited, controlled period of time. 
"I would like there to exist places that are stable, unmoving, intangible, untouched and almost untouchable, unchanging, deep-rooted; places that might be point of reference, of departure, of origin:

[...] such places don't exist, and it's because they don't exist that space becomes a question, ceases to be self-evident, ceases to be incorporated, ceases to be appropriated. Space is a doubt: I have constantly to mark it, to designate it. It's never mine, never given to me, I have to conquer it." (Idem. P. 91)

Freud, Nietzsche, Salomé and other successive philosophers have theorized this as a longing evoked by the first great loss man experiences. A feeling of unity with his surroundings is what a child experiences before being able to speak. As soon as it starts talking, it takes off defining that what meets the senses. By doing so, the I forms itself as an independent and self-defending being, separated by distance and meaning from everything other. A second birth. One which goes along with feelings of abandonment (Salomé, L.A. Terugblik op Mijn Leven; as cited in Hermsen, J.J. 2017, p. 38). In order to survive in a world with many others, to grow up becoming an adult is nothing else than an introduction into the established story and orientation of mature society and its common sense. When the space of the bed is marked and the edges of the room are known, dreams of the infinite far away land are to be converted during geography class into the exact dimensions of countries and continents (Lemaire, T. 1970, p. 13-14). The soul is sold to the devil in exchange for unlimited knowledge, as Oswald Spengler famously relates Goethe's protagonist scholar Faust to modern man.

The philosopher Hannah Arendt too considered an idea she defined as a 'second birth'. She writes, "We are born into this world of plurality where father and mother stand ready for us, ready to receive us and welcome us and guide us and prove that we are not strangers" (Arendt, $\mathrm{H}$. Denktagebuch Notebook 19, Section 39, February, 1954; as cited in Champlin, J. 2012). Jeffrey Champlin, who is an associate fellow at Bard College's Hannah Arendt center, analyses the quote by writing that after getting 'ready' for the child, 'welcoming' it by social incorporation and offering to guide it for a certain amount of time in the world, the 'we' in proving not to be strangers refers to the parents as well. "With word and deed we insert ourselves into the human world," Arendt writes in The Human Condition (1958, p. 176), "and this insertion is like a second birth, in which we confirm and take upon ourselves the naked fact of our physical appearance". In his consideration of this quote, Champlin expresses one of the very essences of Arendt's beliefs; "By speaking of insertion, she indicates making room, a gesture of opening a place. In the second birth, one realizes that the plurality of the world does not simply pre-exist but that our own arrival refigures it" (Champlin, J. 2012). 
The idea Arendt describes as a second birth differs from that of Nietszche, Freud and Salomé in so far that it considers a different moment in growing up. But both concepts have to do with a struggle for space and longing for place, as described by Perec. An issue which has recently been addressed by Herman van Rompuy, the former president of the European Council, when contemplating on the rough times the concept of the European Union has been going through.

"Europe is in fact based on the idea of space, on the concept of the free movement of goods, people and capital, on taking down borders," ..."on being able to communicate everywhere, via telecommunications or by other means." ... "Europe was never thought of as a home, a place, a "Heimat", and to a certain extent we are paying the price for this today." (Rompuy, H. van 2014)

Van Rompuy claims that the emphasis on space has repressed the need for place during recent decades. To serve and develop the free and open market has been more important for decision makers than the European citizen feeling to be at home in the world. The rise of populist beliefs, nationalism, individualism and fear are "not merely a question of politics but also of society," he states.

Today's modern Western reality moves in two opposite directions. On the one hand, as former professor of political thought Margaret Canovan writes in her introduction to Arendt's The Human Condition, "Instead of inhabiting a stable world of objects made to last, human beings [find] themselves sucked into an accelerating process of production and consumption" (Canovan, M. 1998, p. xiv).

"With the immense weight of previous decisions assigned to them even before they are able to assume a role in society, young people might never reach the stage of feeling that they are "not strangers." From this starting point, without having a sense of the welcome of the first birth, they may not be able to make the leap through the "like" to the second birth of making a change in the world." (Champlin, J. 2012)

On the other hand, as a response, society, man, turns inward and creates his own protected reality driven by a melancholic, even nostalgic longing for relational space in order to conquer the feelings of abandonment and loneliness. Feelings which can be addressed to the 'second birth' of Nietzsche, Freud and Salomé.

"Along with the transition from childhood to adolescence, from the imaginary to the symbolic order, man becomes a 'homo melancholicus': one who knows of loss, loneliness and transiency, and will try to turn this into reflection, self- 
awareness and creativity, or supplant it by focussing on power, matter and scattering." (Hermsen, J. 2017) 
The world is that what we, as human beings, construct in order to make human life possible on earth.

The Human Condition, Hannah Arendt, 1958 

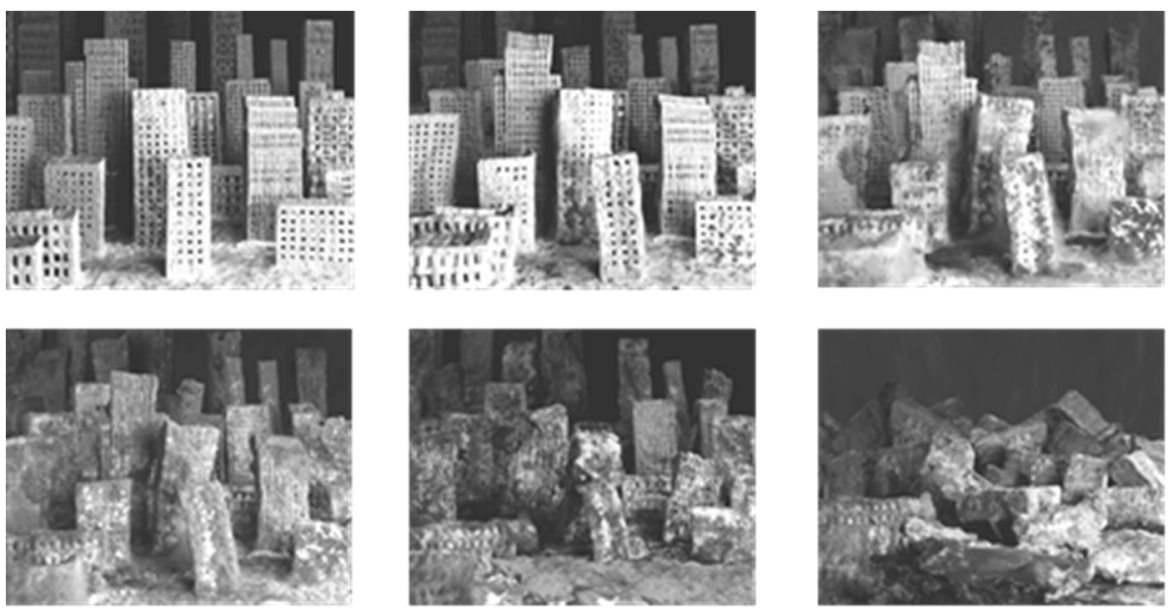

Figure 8. Bread City, 2015 by Johannah Martensson.

"My spaces are fragile: time is going to wear them away, to destroy them. Nothing will any longer resemble what was, my memories will betray me, oblivion will infiltrate my memory, I shall look at a few old yellowing photographs with broken edges without recognizing them. The words 'Phone directory available within' or 'Snacks served at any hour' will nog longer be written up in a semi-circle in white porcelain letters on the window of the little café in the Rue Coquillière.

Space melts like sand running through one's fingers. Time bears it away and leaves me only shapeless shreds:

To write: to try meticulously to retain something, to cause something to survive; to wrest a few precise scraps from the void as it grows, to leave somewhere a furrow, a trace, a mark or a few signs" (Perec, G. 1997, p. 91 92).

The Swedish artist Johannah Martensson has recently build a city out of bread, just to watch it mold. And take photographs to be able to talk about it once it has molded. She constructed a metaphor for a world which has become uninhabitable. A modern world, that of the homeless mind. The pluralistic structures of modern society have made the lives of many individuals migrating, changeable and mobile. In everyday life, the modern individual has to commute constantly between very different and often even contradictory social environments. Besides a growing amount of individuals that have outgrown their places of origin, there are few who are really able to feel 'at home' in a new environment (Berger, P. et al. 1974; as cited in Heijnen, H. 2001 p. 20). 
Modernity, according to Octavio Paz (as cited in Heijnen, H. 2001 p. 33), is an exclusively Western understanding. The Western idea of time differs from other civilizations while it is being thought of as linear, irreversible and ongoing. Seventeenth century humanists have given way to a model of progress, in which each epoch is being perceived as specific and unrepeatable, building on the achievements of previous periods. The timeless time of primitive civilizations or cyclical ideas of time as were common sense in Antiquity were left behind. History has a sense of development which can be influenced into a certain direction.

In the nineteenth century, modernity moves to the foreground of daily lives. A break with fixed values and certainties of tradition can be seen and felt in urban environments. Capitalist structures force the world to develop into a modern direction. Architecture, a cultural activity which can only be realised with money and power, has no other option than to develop aesthetical modern approaches towards civil modernity. It means an acceleration of the world, which puts the need for space, the need to feel at home in the world, at risk (Idem.).

In 1958, Hannah Arendt wrote The Human Condition. Her aim was "nothing more than to think what we are doing" (Arendt, H. 1958). "A reconsideration of the human condition from the vantage point of our newest experiences and our most recent fears."

"At the heart of her analysis of the human condition is the vital importance for civilized existence of a durable human world, built upon the earth to shield us against natural processes and provide a stable setting for our mortal lives. Like a table around which people are gathered, that world "relates and separates men at the same time".

Only the experience of sharing a common human world with others who look at it from different perspectives can enable us to see reality in the round and to develop a shared common sense. Without it, we are each driven back on our own subjective experience, in which only our feelings, wants, and desires have reality" (Canovan, M.; in Arendt, H. 1958).

Feelings, wants and desires man is capable of fulfilling with the ingenuity of today and even more so with further evolving developments in decades ahead. Arendt already feared the growing power of modern man at the time she wrote The Human Condition, it even has been a strong motive for her to write about the importance of what she defines as action. Speech, conversation among human beings, the basis of political life. "There is no reason to doubt our present ability to destroy all organic life on earth. The question is only whether we wish to use our scientific and technical knowledge in this direction," she writes, "It is a political 
question of the first order and therefore can hardly be left to the decision of professional scientists or professional politicians" (idem.).

Action is needed because human beings are plural. Each individual has his own reasoning, his own background, his own story. "Action has no permanence on its own," the architectural theorist Hans Teerds writes, "Action takes place indirectly among humans, without the intercession of thing or matter" (Teerds, H. 2014). But it needs to be heard or seen by other human beings, so is staged in the public realm.

Besides action Arendt defines labor and work as human activities on earth. Labor is done in order to stay alive. Baking bread, harvesting crops, buying groceries. Cyclical movements corresponding to biological life, which produce consumer goods of a short lifespan. Work is what produces the human artifice. A world of things which has a sense of durability, of linear time, and serves action as its stage.

"Human life, according to Arendt, is only possible through the transformation of the "earth" into a world, which is what the products of work do: establishing a world (of things)" (Idem.).

"It is the world that brings us together, not only with our contemporaries but also with our predecessors and forebears" (Arendt, H.; as cited in Idem.). The world has to outlive generations and withstand consumptive processes in order to profoundly stage action. All culture, Arendt states, starts with world-making, production as well as preservation. But in today's centers of modernity, a shift seems to have occurred from the world as a product of work to it being a product of labor. From a durable artifice which offers human beings point of reference and origin, to a consumer good with a short cyclical life-span. 
"We're swimming next to the grass snakes, their heads spying the surface of the water. We're reading the lime white lines which the sinking river leaves behind on the rock as our calendar. We have to go back home again when the lines have the width of our hand. Always with regrets. Always with the burning feeling of a loss at the sticky back seat of the car.

It's an exercise for the future. All of our lives we will have to leave and say goodbye. At first of our youth and the game of imagination. Then of our dreams, our faith, our trust. Even of our elation and our deepest convictions. We'll lose friends, loved ones, parents and children. It's all evenly inevitable, but it starts with saying goodbye to ourselves in a world which naturally embraces us.

We work hard to exorcise our melancholy. Sometimes we scream and sometimes in silence. But all of us reach our arms at a certain moment to the self that once swam to the other side so effortlessly. When the world was still round instead of rectangular. When we just dove into it instead of bumping ourselves over and over again to its sharp edges." (Hermsen J.J. 2018) 
Being modern means that we are surrounded by promises of adventure, power, joy, growth, transformation of ourselves and of the world-but at the same time the threat of destroying everything we have, everything we know, everything we are. (Berman, 1985; as cited in Heijnen, H. 2001).

For as long as human kind exists, it has had to deal with loss, dissapointment and setbacks. With distrust, impotence and incomprehensibilities. Ancient contemplations exist on the feelings of melancholia this evokes in man, from being a disease which had to be cured to being an inexhaustable source of creativity. From being a shared emotion that binds people from all over the world, to being a motive for fear and hate. Feelings that can lead to reflection and renewal, or a focus on scattering, power and matter. In recent decades, man seems more and more unable to deal with these feelings (Hermsen J. J., 2017). Since the twentieth century, melancholia is often medicalized as depression. The use of antidepressants has been quadrupled over the last 25 years, eventhough the effect is still unproven (Idem.).

Melancholia can express itself in conscious memories referring to something which has once been, or in an unconscious longing to something which has never been. Something missing, which cannot clearly be defined. The latter might tempt man to go and search for what has been lost, this makes melancholia a motor behind creativity. But it might also conjure up nostalgic longings to the past. If man loses his faith in progress, he will cherish fear for the future.

Today, it is thoroughly unknown where modern society and the Anthropocene will take man, nor in which direction it has to go, which conjures up a longing for the past, "when things were clear and could be trusted'. A future which seems to offer only losses produces a restless, insecure society (Idem.). Or one which focusses on power and matter, on concealments.

We return to the second birth of Arendt, and the concept of Freud, Nietzsche and Salomé. The first great loss man experiences, is that of unity with his surroundings. Melancholia finds its first origin in growing up, in exchanging the imaginary world for the world of shared common sense. The progressive isolation from everything other a child experiences in growing up in the world, can be bridged by imagination. Being able to feel at home in the world, a unity with one's surroundings, has a strong relation with the range of what is perceived as probable. When a child consciously realises its existence, also the fact that at a certain point their death is inevitable becomes part of their understanding. A fear of death, of temporality, alienates one from the imaginary world in attempts to make the future manageable. Slowly the possibility of unification with the present is lost, the child has become mature (Idem.). 
Whether man is able to turn his melancholic feelings into creativity and reflection, or will conjure up a culture of concealments, depends upon the range of what is perceived as probable in the world, the stories he writes and the strength with which he believes in and holds on to his own construct. To be welcomed in the world being able to refigure it and feel at home, as Arendt emphasizes the important characteristic of the human artifice serving action among plural human beings, has to do with what modern man perceives as probable. But on the other hand "since political action is characterized by frailty, the world needs to be stable in order to give room to the instability and unpredictability of human interactions" (Arendt, H.; as cited by Teerds, H. 2014).

Looking at reason and the world built upon it as a constructable hypothesis, widening the range of what is perceived as probable by modern man threatened by an unpredictable, unknown Anthropocentric future, is in need of certain strong concealments. Of points of reference, spaces of origin. Not just concealments, but consciously selected confrontational differences in time-scales in order to confront modern man with its reality. Evoking moments of 'being,' of widened consciousness in a progressive world which rapidly seems to become uninhabitable. Like the foothills of the Santa-Lucia Range rising firmly out of the tides of the Pacific Ocean, making visible the swell of people that in time will ebb, and all their works dissolve. 
Ah Sun-flower! Weary of time,

Who countest the steps of the Sun:

Seeking after that sweet golden clime

Where the travellers journey is done.

Where the youth pined away with desire,

And the pale Virgin shrouded in snow:

Arise from their graves and aspire,

Where my sun-flower wishes to go.

Songs of Innocence and of Experience: Showing the Two Contrary

States of the Human Soul, William Blake 1794 


\section{BIBLIDGRAPHY}

Arendt, H. (1958). The Human Condition. Chicago: The University of Chicago Press.

Bauman, Z. (2000). Liquid Modernity. Cambridge, UK: Polity Press.

Bauwens, L. (2018, March 19). Mister Motley. Retrieved from Mens-zijn als praktijk - voorbij het post - en transhumanisme:

https://www.mistermotley.nl/tendens/mens-zijn-als-praktijkvoorbij-het-post-en-transhumanisme

Bellos, D. (1999). Species of Spaces and Other Pieces by Georges Perec. Translation Review, 58:1, pp. 53-57.

Berger, P. L., Kellner, H., \& Berger, B. (1973). The homeless mind. Modernization and Consciousness. New York: Random House.

Blackshaw, T. (2005). Zygmunt Bauman. Abingdon, UK: Routledge.

Blake, W. (1794). Songs of Innoncence and of Experience: Showing the Two Contrary States of the Human Soul. London: W. Blake.

Blasdel, A. (2017, June 15). 'A reckoning for our species': the philosopher prophet of the Anthropocene. The Guardian.

Bloom, H. (1988). John Steinbeck. New York City: Chelsea House Publishers.

Braidotti, R. (2013). The Posthuman. Polity Press.

Canovan, M. (1998). Introduction. In H. Arendt, The Human Condition (pp. vii-xx). Chicago: The University of Chicago Press.

Champlin, J. (2012, August 20). Born into a World of Plurality. Retrieved from The Hannah Arendt Center for Politics and Humanities at Bard College: http://69.89.27.220/ hannaha2/born-into-a-worldof-plurality/

Didion, J. (1967, September 23). Slouching Towards Bethlehem. The Saturday Evening Post.

Didion, J. (1968). Goodby to All That. In J. Didion, Slouching Towards Bethlehem. New York: Farrar, Straus and Giroux. 
Didion, J. (1979). The White Album. New York City: Simon \& Schuster.

Frank, R. (2008, May). Men's room, railway station. Retrieved from https://www.lensculture.com/articles/robert-frank-the-americans

Ghosh, A. (2017). The Great Derangement. Chicago: The University of Chicago Press.

Ginsberg, A. (1956). 1926-1997. Howl, And Other Poems. San Francisco: City Lights Pocket Bookshop.

Gorer, G. (1948). The American People: A Study in National Character. New York: W.W. Norton \& Company.

Gornick, V. (2015). The Odd Woman and the City: A Memoir. New York City: Farrar, Straus and Giroux.

Greenough, S. (2010). Introduction. In S. Greenough, \& A. Ginsberg, Beat Memories: The Photographs of Allen Ginsberg. Washington, D.C.: National Gallery of Art (U.S.).

Harvey, D. (2006). Space as a Keyword. In D. Harvey, Spaces of Global Capitalism: Towards a Theory of Uneven Geographical Development (pp. 119-148). London: Verso, New Left Books.

Heijnen, H. (2001). Architectuur en kritiek van de moderniteit [Architecture and Modernity. A Critique]. Nijmegen: Uitgeverij SUN.

Hermsen, J. J. (2017). Melancholie van de Onrust [Melancholia of the unrest]. Amsterdam: bv Uitgeverij de Arbeiderspers.

Hermsen, J. J. (2018). Rivieren keren nooit terug [Rivers never return]. Amsterdam: De Arbeiderspers.

Holmes, J. C. (1952). Go. New York City: Charles Scribner's Sons.

Hunt, T. (2001). The selected poetry of Robinson Jeffers. Palo Alto, CA: Stanford University Press.

Huxley, J. (1957). New Bottles for New Wine. London: Chatto \& Windus.

Jefferson, T. (1787). Notes on the State of Virginia. London: John Stockdale.

Kerouac, J. (1957). On the Road. New York: Viking Press. 
Kerouac, J. (1959). The Americans: Introduction by Jack Kerouac. In R. Frank, The Americans (pp. 1-3). New York: Grove Press.

Kleinpaste, T. (2015). Bevrijd van de mensheid [Liberated from Humanity]. De Groene Amsterdammer, 20-23.

Koolhaas, R. (1978). Delirious New York: A Retroactive Manifesto for Manhattan. New York City: The Monacelli Press.

Latour, B. (1993). The Pasteurization of France. Harvard: Harvard University Press.

Lemaire, T. (1970). Filosofie van het Landschap [Philosophy of the Landscape]. Schoten, Belgium: Uitgeverij Westland nv.

Mak, G. (2012). Reizen zonder John: Op zoek naar Amerika [Travels without John: In Search of America]. Amsterdam/Antwerp: Atlas Contact.

Menand, L. (2007, october 1). Drive, He Wrote: What the Beats were about. The New Yorker.

Morgan, B. (2006). I Celebrate Myself: The Somewhat Private Life of Allen Ginsberg. New York City: Viking.

Morton, T. (2009). Without Nature: Rethinking Environmental Aesthetics. Harvard: Harvard University Press.

Mumford, L. (1931). The Brown Decades: A Study of the Arts in America 1865-1895. New York: Harcourt, Brace and Company.

Negaristani, R. (2014, Februari). The Labor of the Inhuman, Part 1: Human \& Part 2: Inhuman. E-flux journal \#52.

Oey, A. (Director). (2017). VPRO Tegenlicht: Tijdperk van de Mens [VPRO Tegenlicht: The Era of Man] [Motion Picture].

Perec, G. (1997). Espèces d'espaces [Species of Spaces and Other Pieces]. London \& New York: Penguin Books Ltd.

Rahn, J. (2011). The Beat Generation. Retrieved from onlineliterature.com: http://www.onlineliterature.com/periods/beat.php

Rompuy, H. v. (2014). Calm stability in times of crisis. Leiden Europe Lecture. Leiden: Universiteit Leiden, Europa Institute. 
Shield, H. (2015, March 17). The Metaphysics of Oswald Spengler. Retrieved from hammeringshield.wordpress.com: https://hammeringshield.wordpress.com/2015/03/17/themetaphysics-of-oswald-spengler/

Shields, H. (2015, March 19). Culture vs Civilization In Spengler's Decline Of The West. Retrieved from hammeringshield.wordpress.com: https://hammeringshield.wordpress.com/2015/03/19/culture-vscivilization-in-spenglers-decline-of-the-west/

Steinbeck, J. (1945). Cannery Row. New York: Editions for the Armed Services, inc.

Steinbeck, J. (1953). Autobiography: Making of a New Yorker. New York Times. Retrieved from Gothamist.

Steinbeck, J. (1962). Travels with Charley: In Search of America. New York City: Viking Press.

Teerds, H. (2014, July). Constructing Culture: A Political Perspective. Architecture and Culture Volume 2, pp. 213-221.

Vries, J. d. (2015). Met Vijftig Dollar op Zak [With Fifty Dollars in your Pocket]. De Groene Amsterdammer, 118-119.

Vries, J. d. (2019). De methode-Didion: We vertellen onszelf verhalen [The Didion Method: We Tell Ourselves Stories]. De Groene Amsterdammer, 62-65.

Weiner, M. (Director). (2007-2015). Mad Men [Motion Picture]. 
